Research papers

\title{
Seasonal and habitat-wise variations of creek water particulate and dissolved organic carbon in arid mangrove (the Persian Gulf)
}

\author{
R. Ray ${ }^{\mathrm{a}, *, 1}$, M. Weigt ${ }^{\mathrm{b}, \mathrm{c}}$ \\ a Laboratoire des Sciences de l'Environnement Marin, UMR 6539 (UBO/CNRS/IRD/Ifremer), Institut Universitaire Européen de la Mer (IUEM), rue Dumont d'Urville, \\ 29280 Plouzané, France \\ ${ }^{\mathrm{b}}$ Alfred Wegener Institute, Helmholtz Centre for Polar and Marine Research, Am Handelshafen 12, D-27515 Bremerhaven, Germany \\ ${ }^{\mathrm{c}}$ Helmholtz Institute for Functional Marine Biodiversity at the University Oldenburg, Ammerländer Heerstraße 231, 23129 Oldenburg, Germany
}

A R T I C L E IN F O

\section{Keywords:}

Organic carbon

Stable isotope

Mangrove

Non-mangrove

Persian Gulf

\begin{abstract}
A B S T R A C T
The present study examines the effect of mangrove vegetation and different seasons on organic carbon pools, distributions, and source compositions under the stressed hydro-climatological settings of the Iranian coast (Persian Gulf). Significant seasonal and spatial differences were detected only for the $\delta^{13}$ POC (particulate organic carbon) owing to the fluctuation of its sources. Five end-member particulate organic carbon sources (POC) (mangrove leaf, planktonic particles, zooplankton, microphytobenthos (MPB), and sediment) contributed to the POC pool at different levels depending on their seasonal and site-specific abundance. Variations in topographic features such as, the elevations of mangrove and non-mangrove creeks, appeared to play an important role in regulating POC concentrations but not DOC concentrations. Planktonic particles contributed to the POC pool (maximum 10-65\%) at the mangrove sites mostly in the summer whereas the contributions of sediment and MPB (5-35\%) increased in winter. Iranian mangroves are weak exporters of carbon to the Persian Gulf where mangrove plant materials (leaf, litter) had little contributions to the POC and DOC pool (5-25\% and 8-15\%, respectively). It is most likely that OC export in these arid regions are limited by low rainfall and river input. Finally, seasonality and site-specific activity largely control OC dynamics in these relatively understudied arid mangroves.
\end{abstract}

\section{Introduction}

Recent global estimates recognize mangroves as the most carbon (C) rich type of forest ecosystem in the tropics. Globally mangroves store 4-20 billion tons of $C$ in their sediment (Donato et al., 2011), which is five times more than typically observed in temperate, boreal and tropical terrestrial forests on a per-unit-area basis (Bouillon, 2011). Mangrove forests cover $137,760 \mathrm{~km}^{2}$ worldwide, having largest extent found in Asia (42\%) followed by Africa (20\%), North and Central America (15\%), Oceania (12\%) and South America (11\%) (Giri et al., 2011). Mangrove-fringed coastlines are known for actively exchanging materials and organic matter (OM) between terrestrial and marine environments, as regulated by tidal dynamics and geomorphological settings (Adame and Lovelock, 2011). Previous global estimates have shown that mangroves cover only $0.1 \%$ of the earth's continental surface, but account for $11 \%$ of the total input of terrestrial particulate organic carbon (POC) into the ocean (Jennerjahn and Ittekkot, 2002) and $10 \%$ of the terrestrial dissolved organic carbon (DOC) exported to the ocean (Dittmar et al., 2006). Mangroves are complex habitats where trees have developed unique pneumatophores to survive in the relatively anoxic sediment and forest are dissected by numerous channels and creeks that drains water to the adjacent estuary or ocean. These intertidal creeks play an important role in exporting carbon and nutrients through flushing of litter, coarse wood debris, and benthic algae (such as microphytobenthos) or importing them as marine algae within a tidal cycle, thus maintain the productivity of the system (Kristensen and Suraswadi, 2002; Bouillon et al., 2007). Although there are several significant reports about sources and transport of DOC and POC in mangrove dominated coastal systems (Bouillon et al., 2007; Maher et al., 2013; Ho et al., 2017; Ray et al., 2015, 2018a,b), there is a gap in understanding their distribution among different habitats and intertidal creeks. The biogeochemistry of organic carbon (OC) as a function of the presence or absence of mangrove vegetation alongside tidal creeks is particularly important to understand in the context of estuarine and ocean carbon cycles.

The present study complements our previous works on the OC

\footnotetext{
* Corresponding author.

E-mail addresses: raghab.ray@aori.u-tokyo.ac.jp, raghab.ray@gmail.com (R. Ray).

${ }^{1}$ Current address: Department of Chemical Oceanography, Atmosphere and Ocean Research Institute, The University of Tokyo, Kashiwa 277-8564, Japan.
} 
sources to food webs at the northern edges of mangrove distributions in the Indian Ocean where mangroves thrive under extreme temperatures ( $>35^{\circ} \mathrm{C}$ in summer), very low rainfall and high salinities ( $>35 \mathrm{psu}$, Al-Khayat and Jones, 1999). Our previous works at Qeshm Island (Persian Gulf) reported that fish population dynamics and their food sources were related to habitats and seasons (Shahraki and Fry, 2015; Shahraki et al., 2016), and showed the dominance of phytoplankton as sources of DOC and POC in the Iranian mangroves (Ray and Shahraki, 2016). Mangroves in the Persian Gulf have been neglected with respect to OC dynamics. In this context, Qeshm Island is particularly important as a reference site due to the presence of vegetated and non-vegetated areas that can be used to understand the influence of mangrove processes on the distribution of DOC and POC concentrations and their stable isotopes. Furthermore, we consider seasonality as one of the vital factors regulating DOC and POC variations in these mangroves because previous studies in other tropical estuaries and mangroves have shown considerable seasonality in the concentrations and sources of OC and nutrients (Cawley et al., 2013; Leopold et al., 2016; Maher et al., 2013).

Present study is aimed at better understanding the role of habitats and seasons in OC fluctuations in an arid mangrove region. Our main question is: how the distributions and source compositions of DOC and POC vary depending on the presence or absence of mangrove vegetation (i.e., mangrove vs non-mangrove sites) and contrasting seasons? To address this, stable isotopes $\left(\delta^{13} \mathrm{C}, \delta^{15} \mathrm{~N}\right)$ of various end-members such as mangrove leaf, sediment, MPB, planktonic particles and zooplankton were used for mass-based calculations. Multivariate statistical analyses were performed to assess whether DOC and POC differed in concentrations and isotopes between habitats and seasons.

\section{Materials and methods}

\subsection{Study Sites}

The study was carried out at the mangrove and non-mangrove sites of Qeshm Island (Iranian coast of Persian Gulf, $26.8^{\circ} \mathrm{N}, 55.75^{\circ} \mathrm{E}$ ), which has the largest mangrove area in Iran, composed exclusively of Avicennia marina (Fig. 1). Four mangrove-dominated creeks (C1, C2, C3, C4) and two non-mangrove creeks (C5, C6) are studied. Water from both types of creeks ultimately flows into a main channel. C2 and C3 are situated at a lower topographic elevation and were larger in size (low-lying creeks) than C1 and C4 (high-lying creeks) (Fig. 1). The distance between mangrove and non-mangrove creeks is approximately $4 \mathrm{~km}$. C1, C2, C3, and C4 are situated in a pristine environment. Although C5 and C6 are located at the border of a small fishing harbor, the creeks were chosen carefully so that the distance from the harbor would minimize anthropogenic effects on ecosystem carbon dynamics. There are no reefs, seagrass or macroalgae beds in the vicinity of the two sites.

The mangrove forest at Qeshm Island is generally dry implying no tidal water above the sediment interface except on spring tide. Average tidal range is $\sim 2.5 \mathrm{~m}$ in the study area. The mangroves extend $5-50 \mathrm{~m}$ inland as a fringe along the creek banks, and are 3-6 m tall. Sediment texture is dominated by silt and sand (sand: $40.7 \%$, silt: $43.2 \%$, clay: $16.1 \%$, Ali et al., 2017). Further details of the study area can be found in companion papers (Shahraki et al., 2014; Shahraki, 2015; Ray and Shahraki, 2016).

\subsection{Sampling and analytical techniques}

Field campaigns were conducted at the Qeshm Island during winter (2011-2012) and summer (2012). We used a mechanized boat to reach the mouth of all 6 creeks and collected water samples at both high and low tide. Mangrove and non-mangrove sites were similar with respect to many of the measured parameters. Salinity averaged $38.3 \pm 0.5 \mathrm{psu}$ in the mangrove site and $40.3 \pm 2.3 \mathrm{psu}$ in the non-mangrove site, suggesting a stable non-estuarine mangrove environment. Water temperatures in winter averaged $19.6 \pm 1.5^{\circ} \mathrm{C}$ and $19.6 \pm 2{ }^{\circ} \mathrm{C}$ for mangrove and non-mangrove, respectively and $33.7 \pm 1{ }^{\circ} \mathrm{C}$ and $34 \pm 2{ }^{\circ} \mathrm{C}$, in summer, respectively. Table 1 gives the details about the sampling and results of water parameters. Samples of fresh (green) and senescent (yellow) A. marina leaves were hand-picked. Leaf components are potential POC sources in the mangrove surrounding aquatic system due to tidal flushing of leaf/litter debris from the sediment to the adjacent water (Rezende et al., 2007; Ray et al., 2018b). Due to high water residence time at Qeshm Island (Ray and Shahraki, 2016), we expect POC derived from leaf/litter during spring tide would persist still in the water column and contribute to the POC pool.

Decomposing mangrove leaves were also collected from the bottoms of the creeks and combined for analysis of $\mathrm{C}, \mathrm{N}$ and their stable isotopes. During low tide, the top $2 \mathrm{~cm}$ surface sediment was sampled in duplicate with a spoon while MPB were collected by gently scraping off the visible mats. Plankton was sampled at high water after sunset by filtering $10 \mathrm{~L}$ of water through plankton nets $(10 \mu \mathrm{m}$ mesh size). Because it was not possible to obtain phytoplankton samples free of zooplankton, they were considered as mixture of phyto- and zooplankton, whereas zooplankton samples that were caught with a bigger mesh size $(200 \mu \mathrm{m})$ net were only zooplankton. Hence, all plankton samples contained the particles of given sizes. Details of these endmembers collections were described by Shahraki et al. (2014). Water samples were collected in triplicate from the surface using a $2 \mathrm{~L}$ Niskin bottle. Samples were stored in a cool box before filtration of a known volume of tidal water $(250 \mathrm{~mL})$ on pre-weighed and pre-combusted (overnight at $450{ }^{\circ} \mathrm{C}$ ) $47 \mathrm{~mm}$ Whatman GF/F filters ( $0.45 \mu \mathrm{m}$ mesh size), and subsequently dried for analysis of total suspended matter (TSM), plankton and particulate organic carbon (POC) and particulate nitrogen (PN) along with their isotope $\left(\delta^{13} \mathrm{C}, \delta^{15} \mathrm{~N}\right)$. Nutrient samples were collected in $15 \mathrm{~mL}$ plastic tubes for analysis of dissolved nitrogen $\left(\mathrm{NO}_{3} /\right.$ $\mathrm{NO}_{2} / \mathrm{NH}_{4}$ ) and phosphate. Nutrient samples were freeze-dried and silicate samples were kept in a cooler on ice until analyses could be performed.

For DOC and $\delta^{13} \mathrm{DOC}$ analyses, water samples were filtered through syringe filters (cellulose-acetate membrane), stored each in $25 \mathrm{~mL}$ amber glass bottles, acidified with $0.2 \mathrm{M} \mathrm{H}_{3} \mathrm{PO}_{4}$ until the $\mathrm{pH}$ level fell to 2 and kept in a refrigerator. Syringe filters were soaked in deionized distilled water for $24 \mathrm{~h}$. to discard organic leaching before use. DOC samples are available only for the summer collection. All samples (solid, filter and water) were transported to the laboratory on ice for further processing and analysis.

Total organic carbon (TOC) and total nitrogen (TN) content (\%) of the solid powdered samples and filter residues were determined with an Euro EA3000 Elemental Analyzer. Samples for $\delta^{13} \mathrm{C}$ and $\delta^{15} \mathrm{~N}$ were analyzed with a Delta Plus isotope ratio mass spectrometer connected to the Carlo Erba Flash EA elemental analyzer via a Finnigan ConFloII interface. The carbon and nitrogen analysis are expressed in conventional delta $(\delta)$ notation as parts per mil (\%o). The analytical precision (average of measured data subtracted by the arithmetic mean) of the measurement was $<0.12 \%$ for both $\delta^{13} \mathrm{C}$ and $\delta^{15} \mathrm{~N}$. The DOC concentration was determined using a Shimadzu TOC- $\mathrm{V}_{\mathrm{CSH}}$ Analyzer and NDIR detector (non-dispersive infrared detector) calibrated against potassium hydrogen phthalate. DOC stable isotope analysis was carried out at MPI-Jena isotope laboratory (Germany) using a HPLC system coupled to a DELTA ${ }^{\text {plus }}$ XP IRMS through an LC IsoLink interface (Thermo Fisher Scientific, Germany). The $\delta^{13} \mathrm{DOC}$ values were reported as per mil relative to the PDB standard with an overall uncertainty of $\pm 0.10 \%$ (see Ray and Shahraki, 2016 and Scheibe et al., 2012). The study only examines the effect of different seasons on the particulate organic carbon (POC) pools due to the scarcity of dissolved organic carbon (DOC) data in the winter.

Bathymetric surveys of the creeks were carried out at the end of the sampling period in February 2012 to assess the local topography with respect to tidal inundation and drainage patterns. The survey included measuring water levels across different horizontal transects for each 


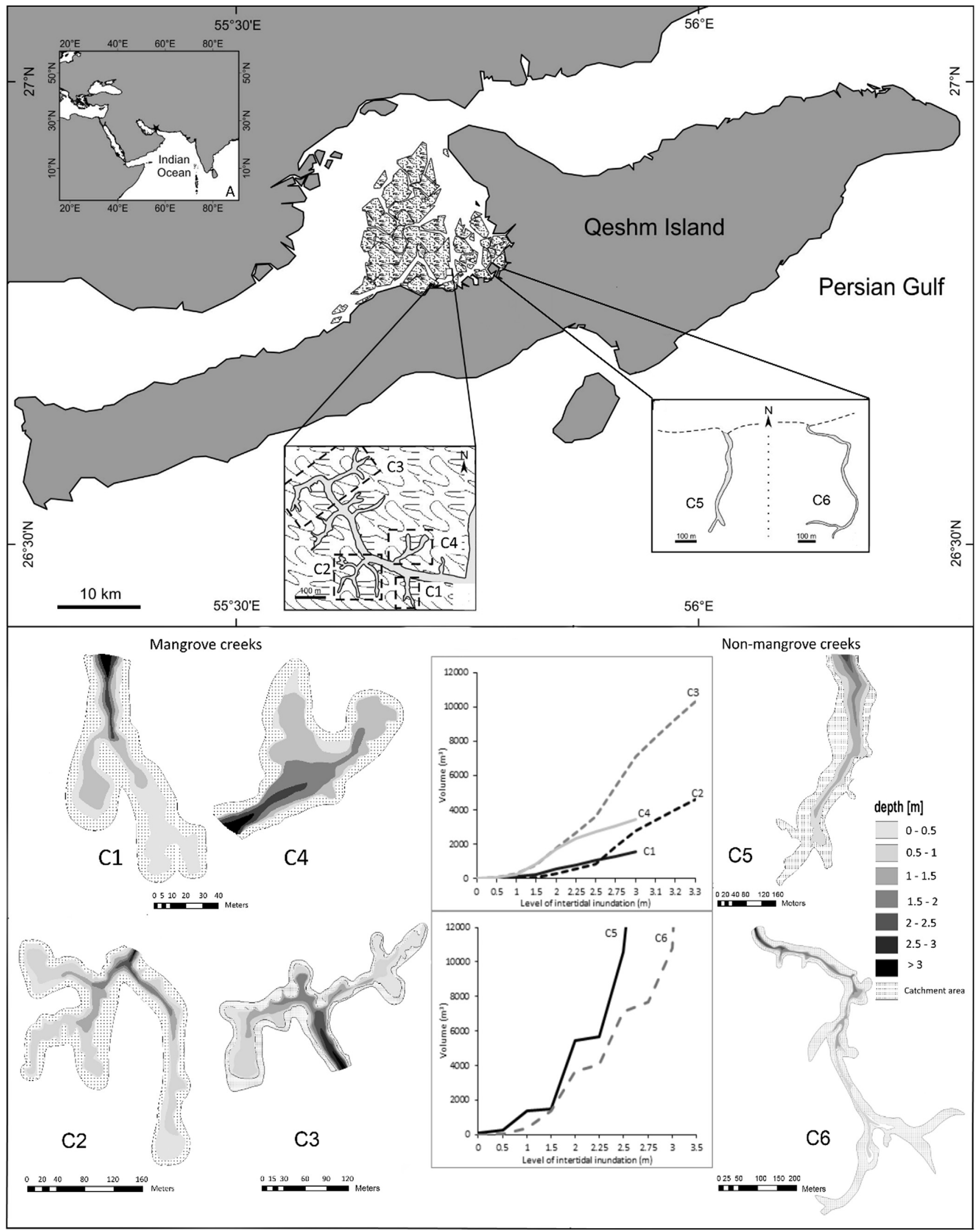

Fig. 1. Location of the study area in the region, sampling sites: mangrove (with four intertidal creeks) and non-mangrove (with 2 intertidal bare creeks), bathymetric maps of creeks 1, 2, 3, 4, 5, and 6. Relationship between level of intertidal inundation and GIS-generated volume $\left(\mathrm{m}^{3}\right)$ are shown in the graphs. 
Table 1

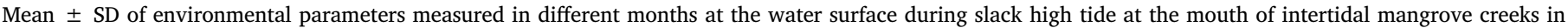

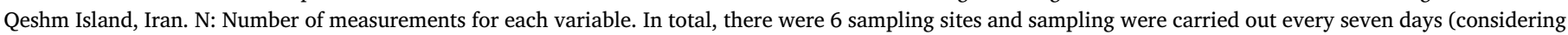
the lunar cycles) and daily cycle (day/night) and 3 months (December, March and August) and total of 96 sampling events.

\begin{tabular}{|c|c|c|c|c|c|}
\hline Sampling Time & $\mathrm{N}$ & Salinity (psu) & Water temperature $\left({ }^{\circ} \mathrm{C}\right)$ & $\mathrm{pH}$ & Oxygen concentration $\left(\mathrm{mg} \mathrm{L}^{-1}\right)$ \\
\hline December 2011-January 2012 & 32 & $38.3 \pm 0.6$ & $19.9 \pm 1.2$ & $8.1 \pm 0.1$ & $8.7 \pm 0.5$ \\
\hline February-March 2012 & 32 & $37.9 \pm 0.4$ & $19.4 \pm 1.7$ & $8.2 \pm 0.7$ & $9.3 \pm 0.7$ \\
\hline August-September 2012 & 32 & $38.7 \pm 0.3$ & $33.7 \pm 1.5$ & $8.2 \pm 0.2$ & $6.5 \pm 1.2$ \\
\hline
\end{tabular}

creek using a tape measure, GPS and a compass, then drawing approximate inundation areas on a grid map in the field. This information was used with GIS software to produce a bathymetric map of each creek (Fig. 1).

\subsection{Data analysis}

\subsubsection{Multivariate approach}

Two-way PERMANOVA (permutational multivariate analysis of variance) models were used to assess whether intertidal POC and PN differed in concentration and $\delta^{13} \mathrm{C}$ and $\delta^{15} \mathrm{~N}$ values between habitats and seasons. Canonical analysis of principal coordinates (CAP) was used as a constrained ordination procedure to visualize significant differences revealed by PERMANOVA. CAP is a canonical multivariate discriminant analysis that maximizes the differences among a priori defined groups. Analyses were performed on square root-transformed data and based on Bray-Curtis distances (Anderson et al., 2008). Due to scarcity of DOC concentration in winter, data were computed only for POC concentration and $\delta^{13} \mathrm{C}$ stable isotope to assess their variations on seasonal and habitat basis.

\subsubsection{End-member mixing model}

Concentration and isotope mixing relationships were examined for POC-based linear mixing correlations $\left(\mathrm{C}\right.$ vs. $\mathrm{Cx}^{13} \mathrm{C}$ ). The purpose of this analysis was to calculate the slope values $\left(\delta^{13} \mathrm{C} \% 0\right)$. Such modelling can provide insights into the source signature of POC at seasonal and spatial scales. Isotope results $\left({ }^{13} \mathrm{C}\right.$ and $\left.{ }^{15} \mathrm{~N}\right)$ of the end-members were used to calculate their contributions (\%) to the POC pool for each creek. In total, five end-members were assessed: mangrove leaf, sediment, MPB, planktonic particles and zooplankton. Due to lack of vegetation at C5 and C6, we applied four end-members excluding mangrove leaf.

In mangrove biogeochemical studies, end-member mixing equations have been used in quite a number of studies that assumed insignificant diagenetic alternations of particulate organic matter (POM) (Ray et al., 2015; Gontharet et al., 2014). The mass balance equations for this study are as follows:

$$
\begin{aligned}
& \delta^{15} \mathrm{~N}_{\text {POM }}=\mathrm{f}_{\text {leaf }} \mathrm{x}\left[\delta^{15} \mathrm{~N}\right]_{\text {leaf }}+\mathrm{f}_{\text {sed }} \mathrm{X}\left[\delta^{15} \mathrm{~N}\right]_{\text {sed }}+\mathrm{f}_{\mathrm{MPB}} \mathrm{X}\left[\delta^{15} \mathrm{~N}\right]_{\text {MPB }} \\
& +\mathrm{f}_{\text {plankton }} \mathrm{x}\left[\delta^{15} \mathrm{~N}\right]_{\text {plankton }}+\mathrm{f}_{\text {zoo }} \mathrm{x}\left[\delta^{15} \mathrm{~N}\right]_{\text {zoo }} \\
& \delta^{13} \mathrm{C}_{\mathrm{POM}}=\mathrm{f}_{\text {leaf }} \mathrm{X}\left[\delta^{13} \mathrm{C}\right]_{\text {leaf }}+\mathrm{f}_{\text {sed }} \mathrm{X}\left[\delta^{13} \mathrm{C}\right]_{\text {sed }}+\mathrm{f}_{\mathrm{MPB}} \mathrm{X}\left[\delta^{13} \mathrm{C}\right]_{\mathrm{MPB}} \\
& +\mathrm{f}_{\text {plankton }} \mathrm{x}\left[\delta^{13} \mathrm{C}\right]_{\text {plankton }}+\mathrm{f}_{\mathrm{zoo}} \mathrm{x}\left[\delta^{13} \mathrm{C}\right]_{\mathrm{zoo}} \\
& f_{\text {leaf }}+f_{\text {sediment }}+f_{M P B}+f_{\text {plankton }}+f_{\text {zooplankton }}=1
\end{aligned}
$$

Where, $\mathrm{f}$ represents relative fractions of each POM sources. The $\delta^{13} \mathrm{C}$ and $\delta^{15} \mathrm{~N}$ isotope values of the habitat-wise different end-members were used to calculate the range of their feasible proportions in the POM. We used IsoSource software (version 1.3.1) to calculate the multiple combinations of the source proportions in given mixture of sample (Phillips and Gregg, 2003) following the above three linear mixing equations. Although IsoSource has proven informative in studies of mangrove contributions in food webs and OC sources (Benstead et al., 2006), there are limitation in the program, like exclusion of degree of fractionations in end-members, and low concentration-dependent adjustments, especially for $\mathrm{N}$ concentration (Phillips and Koch, 2001).
However, in the present study, Isosource constrains the possible contributions to POM pool when the number of sources is large, defining minimum caveats associated with this program. In this procedure, each of the many isotopically feasible solutions can be examined to calculate a proportion for that combined source (Phillips, 2012). These endmember sources are significantly different from each other with regard to their stable isotopes compositions both seasonally and spatially, which was a main reason of choosing them as selective sources of the POM (Student's $t$-test in MINITAB version 13.1: summer mangrove, $t_{46}$ $=-10.5, \mathrm{P}=0.001$; summer non-mangrove, $\mathrm{t}_{22}=-6.66, \mathrm{P}=0.007$; winter mangrove, $\mathrm{t}_{56}=-12.56, \mathrm{P}=0.001$; winter non-mangrove, $\mathrm{t}_{25}$ $=-8.12, \mathrm{P}=0.004)$. As there is no significant difference in $\delta^{13} \mathrm{C}$ signature found between leaf/litter and other mangrove plant organs (like root, branches, twigs), to avoid resulting difficulties in detecting contribution level of each plant sources, only leaf/litter debris are chosen as the representative of plant end-member for POM source identification (Ellison et al., 1996). In this study, sediment and plankton end-members basically represent mixture of eroded debris, and particles of given sizes, respectively. IsoSource analyzed the data at a tolerance level of 0.01 and increment limit of $1 \%$. The particular source increment values of $1 \%$ was chosen as a convenient and appropriate level of precision for examining possible partitioning among sources (Phillips and Gregg, 2003).

Because of logistic reason, we could not collect $\delta^{15} \mathrm{~N}$ of dissolved inorganic/organic N. Therefore, we could not run the IsoSource software for DOM source identification. Instead, we explained the role of mangroves in DOC export (Section 4.3) from our previous results of end-member calculation that applied elemental ratios and isotopes of DOM, leaf, plankton, and MPB (refers to Ray and Shahraki, 2016).

\section{Results}

Seasonal and habitat-wise variations of concentrations and stable isotopes of POC, PN and DOC in all six creeks are shown in Table 2. These parameters varied across the creeks, such as the C3 creek that showed maximum POC and PN concentrations (481 $\pm 13 \mu \mathrm{M}$ and $59 \pm 22 \mu \mathrm{M}$, respectively) in summer when TSM was also highest at the site $\left(511 \pm 185 \mathrm{mg} \mathrm{L}^{-1}\right)$. The $\delta^{13} \mathrm{POC}$ did not change appreciably among mangrove tidal creeks in summer (ranging from -21.4 to $-22.5 \%$ ), however, they were more negative than that found for the non-mangrove creeks (C5: $-19.4 \pm 0.9 \%$; C6: $-17.7 \pm 0.6 \%$ ). Such strong isotopic variations between habitats in summer became marginal in winter when non-mangrove sites exported more negative POC similar to the mangrove sites (C1-4: -21.2 to $-23.2 \%$; C5-6: -23.7 to $-23.9 \%$ ). Taking both seasons into account and averaging POC and $\delta^{13} \mathrm{POC}$ separately for mangrove and non-mangrove creeks, the mangrove habitat had higher concentrations and more negative $\delta^{13} \mathrm{C}(332 \pm 88 \mu \mathrm{M}$ and $-22.3 \pm 0.7 \%$, respectively) than the non-mangrove habitat $\left(264 \pm 70 \mu \mathrm{M}\right.$ and $-21.1 \pm 3.1 \%$, respectively). The $\delta^{15} \mathrm{PN}$ values were relatively higher in summer than winter $(4.6-6.4 \%$ and $3.8-5.5 \%$; respectively), with minimum value found at the non-mangrove creek (C6). DOC concentration did not differ much between habitats, ranging from 302 to $332 \mu \mathrm{M}$ for $\mathrm{C} 1$ to $\mathrm{C} 4$ and $296-309 \mu \mathrm{M}$ for C5 to 6 . The $\delta^{13} \mathrm{DOC}$ was most negative at $\mathrm{C} 3(-25.9 \pm 1.3 \%)$ and most positive at C6 $(-23.2 \pm 1.5 \%)$. 


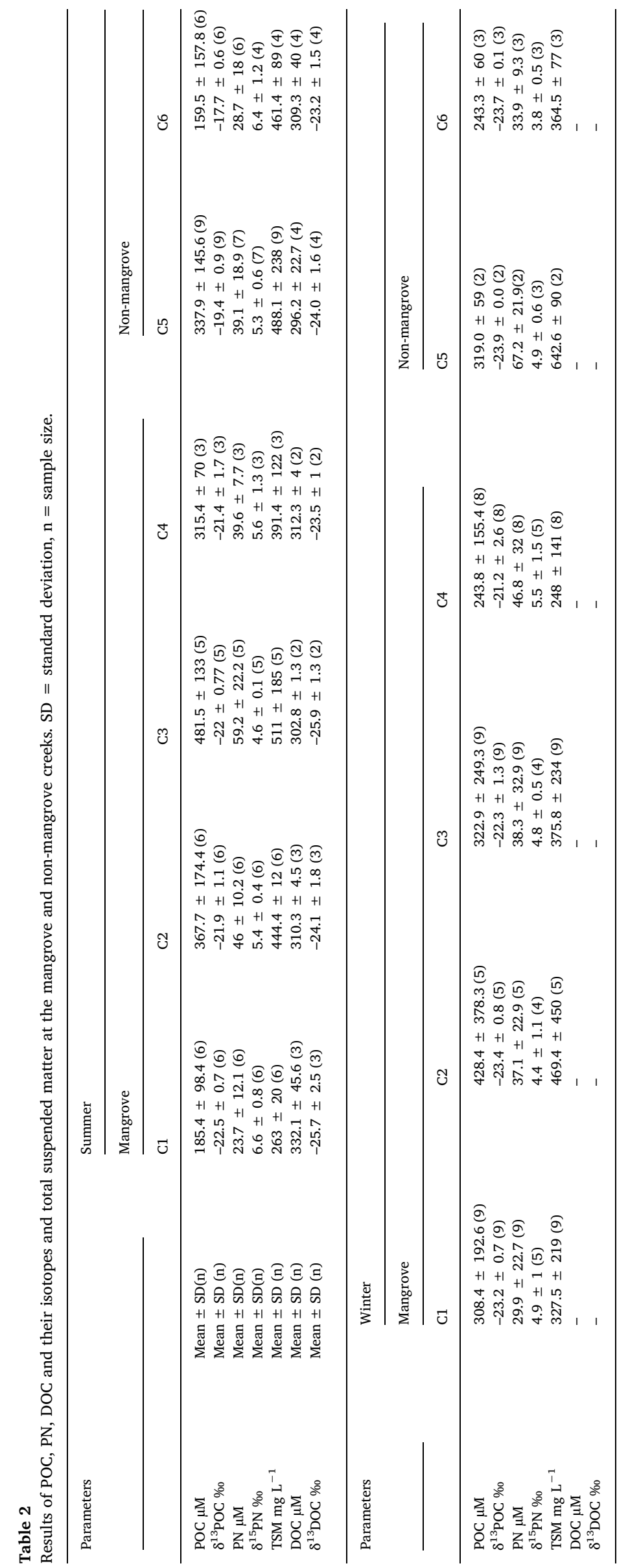


Table 3

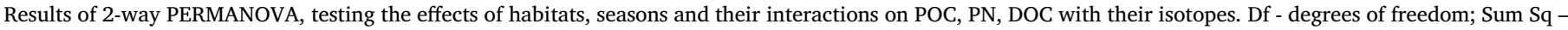
sum of squares; Pseudo -F - F value by permutation, Bold indicates statistical significance with $\mathrm{P}<0.05$, P-values based on 984 permutations.

\begin{tabular}{|c|c|c|c|c|c|c|c|c|c|}
\hline POC & $\mathrm{df}$ & SS & Pseudo-F & $\mathrm{P}($ perm $)$ & $\delta^{13} \mathrm{POC}$ & $\mathrm{df}$ & SS & Pseudo-F & $\mathrm{P}($ perm $)$ \\
\hline Site & 1 & 4518.5 & $3.77 \mathrm{E}-02$ & 0.856 & Site & 1 & 9.5068 & 4.5126 & 0.026 \\
\hline Season & 1 & 48,403 & 0.40403 & 0.555 & Season & 1 & 63.927 & 30.345 & 0.001 \\
\hline SixSe & 1 & 28,005 & 0.23376 & 0.646 & SixSe & 1 & 39.969 & 18.972 & 0.001 \\
\hline Residual & 54 & $6.47 E+06$ & & & Residual & 54 & 113.76 & & \\
\hline $\begin{array}{l}\text { Total } \\
\text { PN }\end{array}$ & 57 & $6.53 E+06$ & & & $\begin{array}{l}\text { Total } \\
\boldsymbol{\delta}^{15} \mathbf{P N}\end{array}$ & 57 & 192.26 & & \\
\hline Site & 1 & 40.914 & 0.029159 & 0.875 & Site & 1 & 1.2606 & 0.64679 & 0.427 \\
\hline Season & 1 & 765.72 & 0.54572 & 0.459 & Season & 1 & 0.14485 & $7.43 E-02$ & 0.799 \\
\hline SixSe & 1 & 341.41 & 0.24332 & 0.615 & SixSe & 1 & 1.6032 & 0.82256 & 0.351 \\
\hline Residual & 54 & 75,769 & & & Residual & 54 & 105.25 & & \\
\hline $\begin{array}{l}\text { Total } \\
\text { DOC }\end{array}$ & 57 & 76,596 & & & $\begin{array}{l}\text { Total } \\
\delta^{13} \text { C DOC }\end{array}$ & 57 & 109.1 & & \\
\hline Site & 1 & 511.99 & 2.1547 & 0.172 & Site & 1 & 21.843 & 3.9738 & 0.061 \\
\hline Residual & 17 & 4039.3 & 237.61 & & Residual & 16 & 87.948 & & \\
\hline Total & 18 & 4551.3 & & & Total & 17 & 109.79 & & \\
\hline
\end{tabular}

PERMANOVA tests showed that seasonal and habitat-level (mangrove vs. non-mangrove) differences in $\delta^{13} \mathrm{POC}$ were significant at the 0.001-0.02 level (Table 3). Interactions between seasons and sites were significant $(\mathrm{P}=0.001)$ only for $\delta^{13} \mathrm{POC}$. Both $\mathrm{PN}$ and $\delta^{15} \mathrm{PN}$ did not show any significant variations between seasons and sites and with their interactions. A weak correlation between the mangrove and nonmangrove sites was observed in summer for DOC $(P=0.172)$ and $\delta^{13} \mathrm{DOC}(\mathrm{P}=0.061)$

Further examination of the significant factors from the PERMANOVA tests of Table 3 was performed (in this case for $\delta^{13} \mathrm{POC}$ ) using the CAP routine with leave-one-out procedures, and results indicated a low overall allocation success for the factor "non-mangrove creeks" (45.5\%) despite being recognized as significant in PERMANOVA tests. However, greater CAP allocation success was achieved for the mangrove creeks (72\%). In general, high allocation success was reported for the seasons, particularly for winter (85\%). Thus, both season and creeks were identified as consistent factors of $\delta^{13} \mathrm{POC}$ variations based on the CAP results (Table 4).

Isotopic mixing results showed significant correlations for POC in all four plots (Fig. 2a, b, c, d). Slopes (i.e. $\delta^{13} \mathrm{C} \%$ ) derived from mixing of $\mathrm{POC}$ and $\delta^{13} \mathrm{POC}$ were stable in the mangrove sites in two seasons unlike at the non-mangroves where it changed from $-19.8 \%$ in winter to $-24.0 \%$ in summer, clearly indicating seasonal effects in modifying POC source signature at the sites.

Results of the seasonal and creek-wise variations for total organic carbon (TOC in \%) and $\delta^{13} \mathrm{C}$ in different organic carbon sources are shown in Tables 5 and 6 , respectively. Leaf and litter at the mangrove creeks contained higher C in winter (41.5-44.4\%) than summer (36.5-39\%). Similar and reverse trends were found for the sediment (0.8-1.3\% in winter and $0.3-0.4 \%$ in summer) and plankton $(1-1.8 \%$ in winter and $1.2-2.6 \%$ in summer), respectively, for both habitats. TOC in zooplankton and MPB did not change appreciably between different seasons and habitats. The $\delta^{13} \mathrm{C}$ in sediment ranged from -15.4 to $-20.3 \%$ in summer and -15.3 to $-22.3 \%$ in winter with heavier carbon obtained for the non-mangrove creeks. Contrasting patterns of $\delta^{13} \mathrm{C}$ in

Table 4

Canonical analysis of principal coordinates (CAP) testing the effect of habitats (mangrove and non-mangrove) and seasons (winter and summer) of the $\delta^{13} \mathrm{POC}$ values. Allocation success $=$ percentage of points correctly allocated into each group; $\delta 2=$ square canonical correlation.

\begin{tabular}{|c|c|c|c|c|c|c|}
\hline Factor & $\mathrm{m}$ & \multicolumn{2}{|c|}{ Allocation success (\%) } & Total & $\delta^{2}$ & $\mathrm{P}$ \\
\hline \multirow[t]{2}{*}{ Habitat } & & Mangrove & Non-mangrove & & & \\
\hline & 1 & 78.7 & 45.4 & 72.4 & 0.04 & 0.02 \\
\hline \multirow[t]{2}{*}{ Season } & & Winter & Summer & & & \\
\hline & 1 & 85.3 & 52.9 & 75.8 & 0.1 & 0.001 \\
\hline
\end{tabular}

MPB was observed between two habitats where non-mangrove creeks contained more positive carbon $(-11 \%)$ than mangrove creeks $(-18.2 \pm 1.1 \% 0)$ in summer and seasonal differences in this pattern was minimal. Results of the $\delta^{15} \mathrm{~N}$ of different end-members are given in Table S1, but detailed discussion of these results are beyond the scope of this article. Similarly, in Table S2 nutrients results were shown for 2 non-mangrove and 1 mangrove sites but these findings are mentioned only briefly in the discussion section.

The contributions of five different end-members to the POM pool at each tidal creek are presented in Fig. 3. Planktonic particles were the large source of POM (range 10-65\%, mean 28\%) in summer while all the end-members made nearly equal contributions in winter (plankton +zooplankton $0-30 \%$, sedimentary OC $5-20 \%$, leaf $5-25 \%$, MPB $25-35 \%)$ at the mangrove sites. For the non-mangrove sites, POC values were mostly composed of plankton (20-60\%) and sediment (33-47\%) in summer whereas all four end-members (planktonic particles, zooplankton, sediment, and MPB) contributed nearly equally in winter (range 10-40\%).

\section{Discussion}

\subsection{Creek morphology, vegetation and carbon dynamics}

In the mangrove sites, C2 and C3 have larger inundation areas during spring tide $\left(6481 \mathrm{~m}^{2}\right.$ and $11,460 \mathrm{~m}^{2}$, respectively) than $\mathrm{C} 1$ and C4 $\left(2774 \mathrm{~m}^{2}\right.$ and $3881 \mathrm{~m}^{2}$, respectively) (Shahraki et al., 2016). Such creek morphology enables the delivery of eroded sediment to the channel water accounting for the high level of TSM and POC at C2 and C3 in both seasons. It was found that POC:TSM weight ratio ranged between $0.9 \%$ and $1.1 \%$ in the low-lying creeks (C2 and C3) being slightly higher than the high-lying creeks (C1 and C4) (0.8-0.9\%) possibly indicating greater soil erosion in these creeks due to more surface area exposed to strong tidal currents. The reverse trend of POC concentration was observed for the non-mangrove creeks where POC at low-lying C6 $\left(10,822 \mathrm{~m}^{2}\right)$ was 1.3-2 times lower than the high-lying C5 $\left(5676 \mathrm{~m}^{2}\right)$. Such deviations of POC content among the creeks could be attributed to factors other than topography because source compositions as indicated by $\delta^{13} \mathrm{POC}$ values in these sites varied between the two seasons ( $P=0.001$, Table 3 ) and eroded sediment and MPB were not always the main sources of suspended organic carbon. Similarly, the isotopic distribution of POC may be less sensitive to topographical differences due to the contributions of multiple sources to the POC pool.

The geomorphology of the creeks had little influence on the DOC variations and source compositions in the water as indicated by the marginal changes in $\delta^{13}$ DOC. It has been proposed that high inundation area and gentle slopes in mangrove ecosystem promote carbon and 

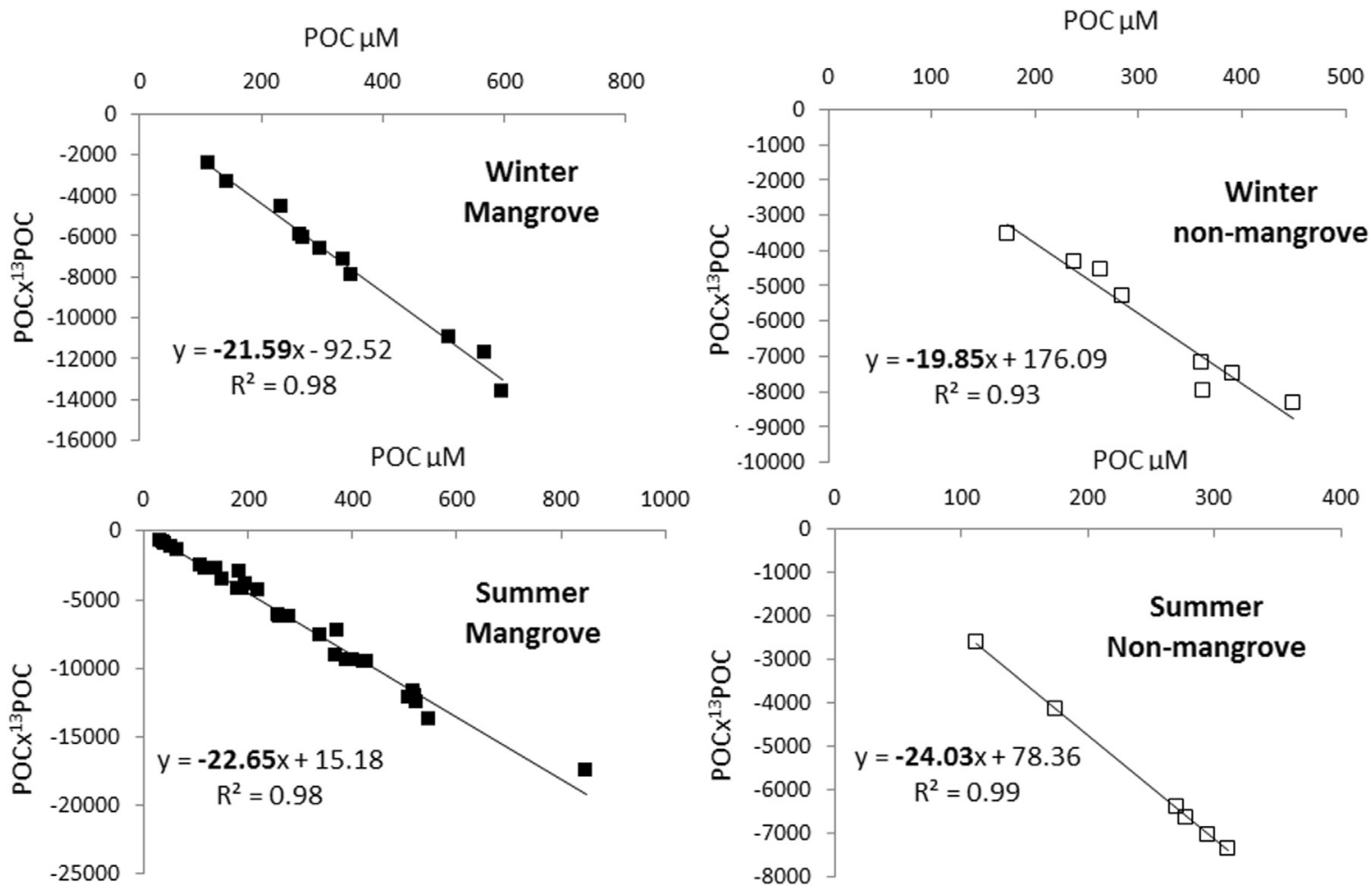

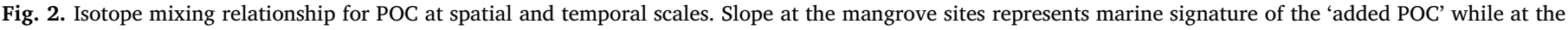
non-mangrove sites shows fluctuations of both marine and terrigenous material between two seasons.

nutrients export to the adjacent coastal water (Adame and Lovelock, 2011), but these had little influence on DOC for the present study. Chaikaew and Chavanich (2017) found local topography and soil drainage were important drivers in determining carbon storage in mangroves of the NE Gulf of Thailand and hypothesized that flat topography in mangroves could weaken erosional processes, resulting in low carbon export and favoring water logged conditions, consequently storing more carbon due to slow decomposition.

Relatively high leaf $\delta^{13} \mathrm{C}$ in mangrove creeks in winter than in summer (difference of $\sim 2 \%$, Table 4 ) is most likely the result of lower isotopic discrimination caused by high water use efficiency as mangroves cope with stressful conditions such as hyper salinity and low rainfall (Ball, 1988; Lin and Sternberg, 1993). Sedimentary OC in both sites is mainly composed of MPB (Ray and Shahraki, 2016); however, greater depletion in $\delta^{13} \mathrm{C}$ in the mangroves sites is attributed to the incorporation of more negative carbon of mangrove origin into the $\mathrm{OC}$ pool. Higher values of $\delta^{13} \mathrm{C}$ of MPB at C5 and C6 in both seasons (mean $\sim-13 \%$ ) could reflect high rates of production by benthic algae growing in high sunlight in the absence of shading by mangroves. At the non-mangrove creeks, low $\delta^{15} \mathrm{~N}$ of MPB (Table S1) reflect the dominance of $\mathrm{N}_{2}$ fixing cyanobacteria, which are known to have the most positive $\delta^{13} \mathrm{C}$ values among aquatic autotrophs (e.g. Shahraki et al., 2014; Al-Zaidan et al., 2006).

\subsection{Role of mangroves in POC export}

Both habitat and season emerged as important and significant drivers of $\delta^{13} \mathrm{POC}$ variations in Qeshm mangroves. Planktonic particles dominated in the mangrove sites in summer whereas, terrigenous organic carbon (leaf, sedimentary OC, MPB) contributed mostly to the POC pool in winter.

Given the lack of other productive habitats in the proximity to the Qeshm mangroves, the low contribution of mangroves to the POC pools may be mainly due to low productivity in arid environments that lack freshwater input. Furthermore, isotopic mixing results in mangrove sites suggest that plankton are the primary source of POC in the water during both seasons (Fig. 2a, c) and that these arid mangrove sites are importing POC. In contrast, wet mangrove ecosystems export POC to the coastal water (e.g. Brazilian mangroves, Rezende et al., 2007; Indian Sundarbans, Ray et al., 2018b). Under similar arid settings, Almahasheer et al. (2017) also reported lack of terrigenous input to the POC pool $\left(\delta^{13} \mathrm{C}=-11.3 \pm 1.6 \%\right.$ ) for the Red Sea mangroves rather POC source were limited to marine phytoplankton production and import from the sea. Significant seasonality of POC source compositions was observed for the non-mangroves where apart from sediment, plankton and MPB, other external sources such as sewage from the local harbor (a few hundred meters away) may also contribute to the POC pool in summer (Fig. 2b, d). Though C5 and C6 were located at a distance from such effects, there may have been sewage inputs at C6, as evidenced by relatively positive $\delta^{13} \mathrm{POC}(-17.7 \% 0)$ and the $\delta^{15} \mathrm{PN}$ $(3.8 \%)$ which were similar to the values reported for sewage-derived POM around the US coasts ( $-16.5 \%$ and $2.5 \%$ respectively; Van Dover et al., 1992; Spies et al., 1989; Sweeney and Kaplan, 1980). However, the variation in nutrient concentrations was fairly low in both habitats, with dissolved inorganic nitrogen $\left(\mathrm{NO}_{3}+\mathrm{NH}_{4}+\mathrm{NO}_{2}\right)$ and phosphate concentrations were $<5 \mu \mathrm{M}$ and $<0.5 \mu \mathrm{M}$, respectively (Table S2), suggesting insignificant effects on the water quality arising from sewage disposal. Also elevated oxygen levels at both sites ( $>100 \%$ saturation) suggested low biochemical oxygen demand (BOD). Therefore, anthropogenic $\mathrm{OC}$ sources at the non-mangrove and mangrove sites appear to be negligible. Evidence that marine and/or algal-derived OM are the major sources of POM include minimal seasonal and site-specific variations in $\mathrm{PN}$ and $\delta^{15} \mathrm{PN}$ that could be attributed to the perennial source of both pelagic and benthic algae in the POM. This is consistent with our previous study that showed insignificant contributions of mangrove plants to the PN pool (Ray and Shahraki, 2016), which is further reflected by the PERMANOVA results (Table $3, \mathrm{p}>0.05$ ) between mangrove and non-mangrove sites.

Arid mangrove stands in Iran were effective retainers of most of their production due to minimum rainfall, and the absence of river 


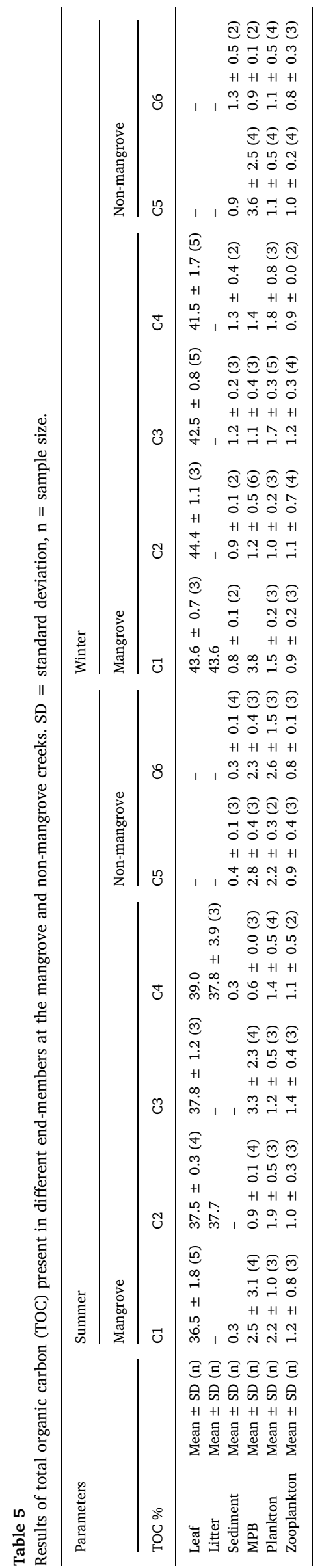

discharge that could drive hydrologic export (i.e. outwelling) of OC from the forest floor. Evidence of OC retention owing to input from the seagrasses was shown by Walton et al. (2014) for the similar arid mangroves in Qatar; however, such vegetation is absent in our study sites, meaning only mangrove-derived carbon would be available for export to the sea. The absence of rainfall appears to significantly reduce outwelling from arid mangrove ecosystems (Loneragan et al., 1997) and may explain carbon retention in arid mangrove ecosystems similar to the Qeshm Island mangroves (Schile et al., 2016). Leaf-litter processing by crabs may significantly reduce the amount of mangrove-derived POC available for export (Olafsson et al., 2002; Kristensen, 2008). In the Gazi Bay mangroves (Kenya), Andreetta et al. (2014) observed that burrowing sesarmid crabs living under the vegetation potentially preserved OC in the deeper sediment while MPB could supply OC in the surface sediment. Shahraki et al. (2014) observed that microbenthic feeders such as Pentaprion longimanus, Acanthopagrus latus, and Pomadasys kaakan in both mangrove and non-mangroves sites at Qeshm Island relied on MPB as a food source. Because leaf-eating crabs reduce the availability of MPB (one of the main sources of POC) for export through burial, we may further infer that POC export from the Qeshm Island mangroves is regulated by hydrodynamics (rainfall setting, tidal regime), habitat (mangrove, non-mangrove), and faunal benthic activity.

\subsection{Role of mangroves in DOC export}

Leaching of mangrove plant materials through surface and pore water export are generally recognized as the major pathways of DOC transport into the mangrove-dominated coastal waters (Bouillon et al., 2007; Dittmar and Lara, 2001; Troxler et al., 2015). Below ground properties, such as mangrove pore water generally contains $2-3$ times higher DOC concentration than overlying water (Ray et al., 2018a) accelerating DOC export via tidal pumping and seepage. However, our previous results at Qeshm mangroves showed such terrigenous DOC output less effective than marine DOC input (Ray and Shahraki, 2016). The same report calculated marine algae as highest contributor to DOC (mean $82 \%$, range $80-86 \%$ ), followed by mangrove leaves $(12 \%$, 8-15\%), suggesting oceanic import dominated over mangrove-derived DOC export. Ray and Shahraki et al. (2016) further suggested that the high residence time of water in the Gulf promoted high phytoplankton biomass and thus high rates of DOC input from phytoplankton decomposition. This result contrasts with more humid tropical mangroves where mangrove-derived DOC export to the sea was reported to be large and mangroves contributed significantly to the DOC pool. For example, mangrove-derived DOC is important in the Sundarbans (Ray et al., 2018b), Everglades (Ho et al., 2017) and Brazilian mangroves (Rezende et al., 2007). This assumption of weak DOC export from Qeshm Island is supported by the PERMANOVA results that show almost no variations in DOC concentrations or isotopic signatures between mangrove and non-mangrove sites. We expected greater variability between these different habitats due to DOC leaching from mangrove plants and pore water. Isotopic results in both habitats suggest a mixture of sources in the DOC pool where pelagic contribution would be greater relative to mangroves and other allochthonous sources (like effluents from nearby fishing harbor). Despite the lack of freshwater input and rainfall at these Iranian intertidal sites, phytoplankton production is sustained by sufficient sunlight and nutrients imported from the sea for sustained in-situ production (Ray et al., 2016). Hence, phytoplankton DOC release is important apart from other mechanisms such as grazer excretion and cellular lysis (Rushansky and Legrand, 1996). Low mangrove contributions to the DOC export could be attributed to the biophysical factors such as, (1) hydrology (low river runoff and rainfall) and (2) biology (low forest productivity).

With regard to hydrological factors, minimum freshwater input and rainfall throughout the year, is probably the key reason of low mangrove exports of OC (both DOC and POC) unlike in Everglades, where 
Table 6

Results of $\delta^{13} \mathrm{C}$ of the TOC present in different end-members at the mangrove and non-mangrove creeks. SD $=$ standard deviation, $\mathrm{n}=$ sample size.

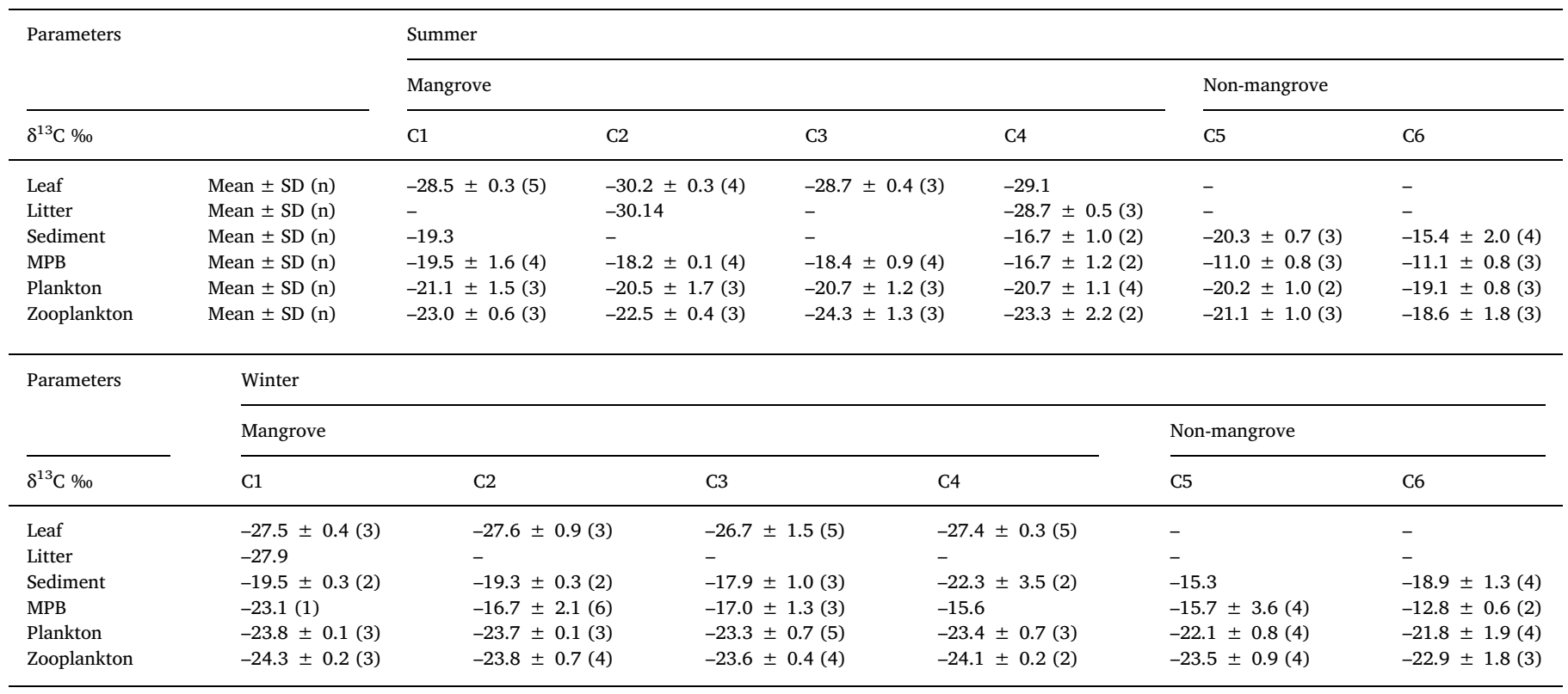

*MPB $=$ microphytobenthos.

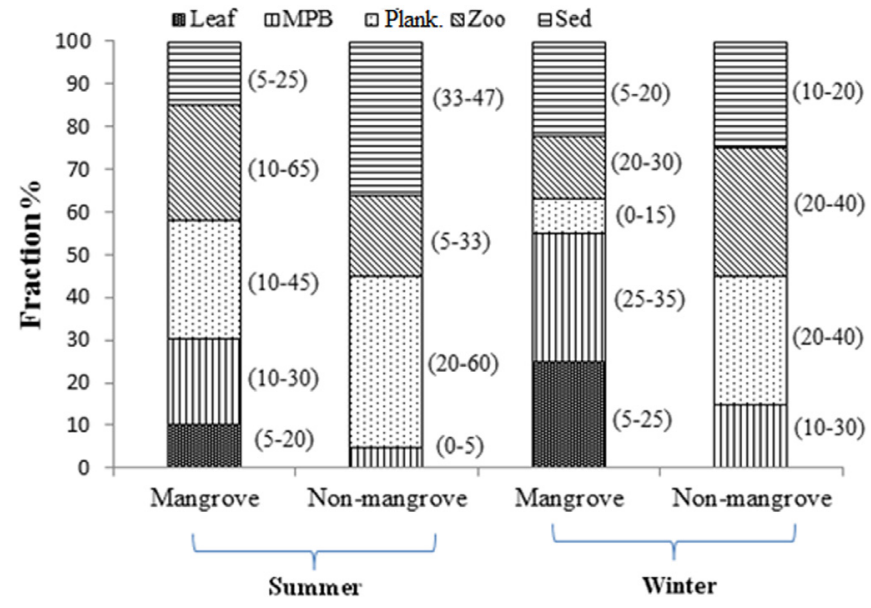

Fig. 3. End-member mixing results yield various proportion of sources in the POC pool based on season (winter and summer) and habitat (mangrove and non-mangrove). Mean contributions (\%) of sources are plotted while ranges of contributions derived from Isosource model are shown besides the bars. In the legend, Plank. and Zoo represent planktonic particles and zooplankton, respectively.

their export increased 5-10 fold during the rainy season (Bergamaschi et al., 2012, Cawley et al., 2013). A similar argument was given for higher DOC during the rainy season in the Brazilian mangroves by Dittmar et al. (2001). The absence of rainfall appeared to significantly reduce export from mangroves of Gulf of Carpentaria, Australia and partly explained carbon retention in the estuary (Loneragan et al., 1997). In addition to these factors, the tidal flat is inundated only during spring tide, so the lack of tidal flushing and pore water exchange could be another reason for weak DOC export by these mangroves.

With regard to biological factors, low productivity of these dry mangroves could also account for this trend of weak OC export. Although the measurements of forest productivity at Qeshm Island are scarce, we found trees are $3-6 \mathrm{~m}$ in height, which is much lower than more humid tropical mangroves (French Guiana: 4-20 m, Fromard et al., 2004; Indian Sundarbans: 4-10 m, Ray et al., 2011; Indonesia: 21-26 m, Komiyama et al., 1988, 2008; Malaysia: $15 \mathrm{~m}$, Ong et al., 1982). Arid mangroves around Persian Gulf tend to have low OC $(<1 \%$, this study) in the sediment compared to other wet mangroves ( $>10 \%$, Indo-Pacific mangroves, Donato et al., 2011). Poor OC preservation was reported for the arid mangroves in the United Arab Emirates (sequestration rate $=15 \mathrm{~g} \mathrm{C}_{\text {org }} \mathrm{m}^{-2} \mathrm{yr}^{-1}$, 10-fold less than global mean) due to the oligotrophic nature and low mangrove inputs to the Red Sea (Almahasheer et al., 2017; Schile et al., 2016), like the present settings of the Iranian mangroves. Although there is no report of direct measurement of litter fall or live biomass for the Iranian mangroves, it can be presumed that a higher ratio of sand in the sediment of Qeshm Island mangroves ( $>50 \%$, Ansari et al., 2014) and stressful environmental conditions (very hot summer and cold winter, very little rainfall and hyper salinity) are not conducive for mangrove plant growth.

\section{Conclusion}

Major conclusions from this study are:

(1) Mangrove vegetation has negligible role in the POC dynamics of the near-shore waters of Qeshm Island. Although mangrove contributes up to $25 \%$ of the DOC pool, their role in exporting DOC is small. Marine import of planktonic OC could account for the observed DOC and POC concentrations and isotopic variations rather than mangrove-derived export of these compounds.

(2) Seasonality and site-specific features are more significant for POC than DOC.

(3) Multiple biophysical factors such as lack of fresh water, thermal stress, hyper-salinity, and low plant productivity might be responsible for low rates of OC export from mangroves to the Persian Gulf.

\section{Acknowledgements}

The project was supported by 'Leibniz Center for Tropical Marine Ecology (ZMT) Project Number 7109'. Thanks are due to our boatman, 
helpers and field partners. We sincerely thank D. Dasbach, M. Birkicht (ZMT) and A. Malik (MPI-Jena) for providing laboratory support. We sincerely thank Dr. Patrick Megonigal, Smithsonian Environmental Research Center, USA for editing and scientific inputs that greatly improved the manuscript. We thank the Editor and two anonymous reviewers for their insightful comments.

\section{Appendix A. Supporting information}

Supplementary data associated with this article can be found in the online version at http://dx.doi.org/10.1016/j.csr.2018.06.009.

\section{References}

Adame, M.E., Lovelock, C.E., 2011. Carbon and nutrient exchange of mangrove forests with the coastal ocean. Hydrobiology 663, 23-50.

Al-Khayat, J.A., Jones, D.A., 1999. A comparison of the macrofauna of natural and replanted mangroves in Qatar. Estuar. Coast. Shelf Sci. 49, 55-63.

Ali, R.J., Alireza, R.B., Mansour, A., Amirhossein, S.T., 2017. Spatial distribution and composition of aliphatic hydrocarbons, polycyclic aromatic hydrocarbons and hopanes in superficial sediments of the coral reefs of the Persian Gulf, 346 Iran. Environ. Pollut (16)(31805-X. doi:347 10.1016/j.envpol.2017.01.080).

Almahasheer, H., Serrano, O., Duarte, C.M., Arias-Ortiz, A., Masque, P., Irigoie, X., 2017. Low carbon sink capacity of Red Sea mangroves. Sci. Rep. 7, 9700. http://dx.doi.org/ 10.1038/s41598-017-10424-9.

Al-Zaidan, A., Kennedy, H., Jones, D., Al-Mohanna, S., 2006. Role of microbial mats in Sulaibikhat Bay (Kuwait) mudflat food webs: evidence from $\delta^{13} \mathrm{C}$ analysis. Mar. Ecol. Prog. Ser. 308, 27-36.

Anderson M., Gorley R. and Clarke K., 2008. UK: PRIMER-E, Plymouth. PERMANOVA+ for PRIMER: guide to software and statistical methods: 214 .

Andreetta, A., Fusi, M., Cameldi, I., Cimò, F., Carnicelli, S., Cannicci, S., 2014. Mangrove carbon sink. Do burrowing crabs contribute to sediment carbon storage? Evidence from a Kenyan mangrove system. J. Sea Res. 85, 524-533.

Ansari, Z., Seyfabadi, J., Owfi, F., Rahimi, M., 2014. Habitat classification of the southern coast of Qeshm Island based on surface geology structure. Indian J. Mar. Sci. 43, $1753-1763$.

Ball, M.C., 1988. Salinity tolerance in the mangroves Aegiceras corniculatum and Avicennia marina. I. Water use in relation to growth, carbon partitioning, and salt balance. Aust. J. Plant Physiol. 15, 447-464.

Benstead, J.P., March, J.G., Fry, B., Ewel, K.C., Pringle, C.M., 2006. Testing IsoSource: stable isotope analysis of a tropical fishery with diverse organic matter sources. Ecology 87, 326-333.

Bergamaschi, B.A., Krabbenhoft, D.P., Aiken, G.R., Patino, E., Rumbold, D.G., Orem, W.H., 2012. Tidally driven export of dissolved organic carbon, total mercury, and methyl mercury from a mangrove-dominated estuary. Environ. Sci. Technol. 46, $1371-1378$.

Bouillon, S., 2011. Carbon cycle: storage beneath mangroves. Nat. Geosci. 4, 282-283. http://dx.doi.org/10.1038/ngeo1130.

Bouillon, S., Middelburg, J.J., Dehairs, F., Borges, A.V., Abril, G., Flindt, M.R., Ulomi, S., Kristensen, S.E., 2007. Importance of intertidal sediment processes and pore water exchange on the water column biogeochemistry in a pristine mangrove creek (RasDege, Tanzania). Biogeosciences 4, 311-322.

Cawley, K.M., Yamashita, Y., Maie, N., Jaffé, R., 2013. Using optical properties to quantify fringe mangrove inputs to the dissolved organic matter (DOM) pool in a subtropical estuary. Estuaries Coasts 37, 399-410.

Chaikaew, P., Chavanich, S., 2017. Spatial variability and relationship of mangrove soil organic matter to organic carbon. Appl. Environ. Soil Sci. 4010381. http://dx.doi. org $/ 10.1155 / 2017 / 4010381$

Dittmar, T., Hertkorn, N., Kattner, G., Lara, R.J., 2006. Mangroves, a major source of dissolved organic carbon to the oceans. Glob. Biogeochem. Cycles 20 (1), GB1012. http://dx.doi.org/10.1029/2005GB002570.

Dittmar, T., Lara, R.J., Kattner, G., 2001. River or mangrove? Tracing major organic matter sources in tropical Brazilian coastal waters. Mar. Chem. 73, 253-271.

Donato, D.C., Kauffman, J.B., Murdiyarso, D., Kurnianto, S., Stidham, M., Kanninen, M., 2011. Mangroves among the most carbon-rich forests in the tropics. Nat. Geosci. 4, 293-297.

Ellison, A.M., Farnsworth, E.J., Twilley, R.R., 1996. Facultative mutualism between red mangroves and root-fouling sponges in Belizean mangal. Ecology 77, 2431-2444.

Fromard, F., Vega, C., Proisy, C., 2004. Half a century of dynamic coastal change affecting mangrove shorelines of French Guiana. A case study based on remote sensing data analyses and field surveys. Mar. Geol. 208, 265-280.

Giri, C., Ochieng, E., Tieszen, L.L., Zhu, Z., Singh, A., Loveland, T., Masek, J., Duke, N., 2011. Status and distribution of mangrove forests of the world using earth observation satellite data. Glob. Ecol. Biogeogr. 20, 154-159.

Gontharet, S., Mathieu, O., Leveque, J., Milloux, M.-J., Lesourd, S., Philippe, S., Caillaud, J., Gardel, A., Sarrazin, M., Proisy, C., 2014. Distribution and sources of bulk organic matter (OM) on a tropical intertidal mud bank in French Guiana from elemental and isotopic proxies. Chem. Geol. 376, 1-10.
Ho, D.T., Ferrón, S., Engel, V.C., Anderson, W.T., Swart, P.K., Price, R.M., Barbero, L., 2017. Dissolved carbon biogeochemistry and export in mangrove dominated rivers of the Florida Everglades. Biogeosciences 14, 2543-2559.

Jennerjahn, T.C., Ittekkot, V., 2002. Relevance of mangroves for the production and deposition of organic matter along tropical continental margins. Naturwissenschaften 89, 23-30.

Komiyama, A., Ong, J.E., Poungparn, S., 2008. Allometry, biomass, and productivity of mangrove forests: a review. Aquat. Bot. 89, 128-137.

Komiyama, A., Moriya, H., Prawiroatmodjo, S., Toma, T., Ogino, K., 1988. Forest primary productivity. In: Ogino, K., Chihara, M. (Eds.), Biological System of Mangrove. Ehime University, pp. 97-117.

Kristensen, E., Suraswadi, P., 2002. Carbon, nitrogen and phosphorus dynamics in creek water of a southeast Asian mangrove forest. Hydrobiologia 474, 197-211.

Kristensen, E., 2008. Mangrove crabs as ecosystem engineers; with emphasis on sediment processes. J. Sea Res. 59, 30-43.

Leopold, A., Marchand, C., Deborde, J., Allenbach, M., 2016. Water biogeochemistry of a mangrove-dominated estuary under a semi-arid climate (New Caledonia). Estuaries Coasts. http://dx.doi.org/10.1007/s12237-016-0179-9.

Lin, G., Sternberg, L.S.L., 1993. Comparative study of water uptake and photosynthetic gas exchange between scrub and fringe red mangroves, Rhizophora mangle L. Oecologia 90, 399-403.

Loneragan, N.R., Bunn, S.E., Kellaway, D.M., 1997. Are mangroves and seagrasses sources of organic carbon for penaeid prawns in a tropical Australian estuary? A multiple stable- isotope study. Mar. Biol. 130, 289-300.

Maher, D.T., Santos, I.R., Golsby-Smith, L., Gleeson, J., Eyre, B.D., 2013. Groundwaterderived dissolved inorganic and organic carbon exports from a mangrove tidal creek: the missing mangrove carbon sink? Limnol. Oceanogr. 58, 475-488.

Olafsson, E., Buchmayer, S., Skov, M.W., 2002. The East African decapod crab Neosarmatiummeinerti (de Man) sweeps mangrove floors clean of leaf litter. Ambio 31, 569-573.

Ong, J.E., Gong, W.K., Wong, C.H., 1982. Studies on Nutrient Levels in Standing Biomass, Litter and Slash in a Mangrove Forest. BIOTROP, Bogor, p. 44.

Phillips, D.L., Koch, P.L., 2001. Incorporating concentration dependence in stable isotope mixing models. Oecologia 130, 114-125.

Phillips, D.L., Gregg, J.W., 2003. Source partitioning using stable isotopes: coping with too many sources. Oecologia 136, 261-269.

Phillips, D.L., 2012. Converting isotope values to diet composition: the use of mixing models. J. Mammal. 93, 342-352.

Ray, R., Ganguly, D., Chowdhury, C., Dey, M., Das, S., Dutta, M.K., Mandal, S.K., Majumder, N., De, T.K., Mukhopadhyay, S.M., Jana, T.K., 2011. Carbon sequestration and annual increase of carbon stock in a mangrove forest. Atmos. Environ. 45, 5016-5024.

Ray, R., Rixen, T., Baum, A., Malik, A., Gleixner, G., Jana, T.K., 2015. Distribution, sources and biogeochemistry of organic matter in a mangrove dominated estuarine system (Indian Sundarbans) during the pre-monsoon. Estuar. Coast. Shelf Sci. 167, 404-413.

Ray, R., Shahraki, M., 2016. Multiple sources driving the organic matter dynamics in two contrasting tropical mangroves. Sci. Total Environ. 571, 218-227.

Ray, R., Michaud, E., Aller, R.C., Vantrepotte, V., Gleixner, G., Walcker, R., Devesa, J., Le Goff, M., Morvan, S., Thouzeau, G., 2018a. Sources and distribution of carbon (DOC, POC, DIC) in a mangrove dominated estuary (French Guiana, South America). Biogeochem. 138, 297-321.

Ray, R., Baum, A., Gleixner, G., Rixen, T., Jana, T.K., 2018b. Exportation of dissolved (inorganic and organic) and particulate carbon from mangroves and their implications to the carbon budget in the Indian Sundarbans. Sci. Total Environ. 621 $535-547$.

Rezende, C.E., Lacerda, L.D., Ovalle, A.R.C., Silva, L.F.F., 2007. Dial organic carbon fluctuations in a mangrove tidal creek in Sepetiba bay, Southeast Brazil. Braz. J. Biol. 67, 673-680.

Rushansky, N.Z.M., Legrand, C., 1996. Excretion of dissolved organic carbon by phytoplankton of different sizes and subsequent bacterial uptake. Mar. Ecol. Prog. Ser. 132, 249-255.

Scheibe, A., Krantz, L., Gleixner, G., 2012. Simultaneous determination of the quantity and isotopic signature of dissolved organic matter from soil water using high-performance liquid chromatography/isotope ratio mass spectrometry. Rapid Commun. Mass Spectrom. 26, 173-180.

Schile, L.M., Kauffman, J.B., Crooks, S., Fourquren, J.W., Glavan, J., Megonigal, J.P., 2016. Limits on carbon sequestration in arid blue carbon ecosystems. Ecol. Appl. 27, 859-874.

Shahraki, M., Fry, B., Krumme, U., Rixen, T., 2014. Microphytobenthos sustain fish food webs in intertidal arid habitats: a comparison between mangrove-lined and un-vegetated creeks in the Persian Gulf. Estuaries Coast. Shelf Sci. 149, 203-212.

Shahraki, M., Fry, B., 2015. Seasonal fisheries changes in low rainfall mangrove ecosystems of Iran. Estuaries Coasts. http://dx.doi.org/10.1007/s12237-015-0004-x.

Shahraki, M., 2015. Fish Community Structure and Food Web Dynamics in Low Rainfall Mangrove and Non-mangrove Ecosystems (Persian Gulf). Staats-und Universitätsbibliothek, Bremen.

Shahraki, M., Saint-Paul, M.U., Krumme, U., Fry, B., 2016. Fish use of intertidal mangrove creeks at Qeshm Island, Iran. Mar. Ecol. Prog. Ser. 542, 153-166.

Spies, R.B., Kruger, H., Ireland, R., Rice, D.W., 1989. Stable isotope ratios and contaminant concentrations in a sewage distorted food web. Mar. Ecol. Prog. Ser. 54, 157170.

Sweeney, R.E., Kaplan, I.R., 1980. Tracing flocculent industrial and domestic sewage 
transport on San Pedro shelf, southern California, by nitrogen and sulphur isotope ratios. Mar. Environ. Res. 3, 215224.

Troxler, T.G., Barr, J.G., Fuentes, J.D., Engel, V., Anderson, G., Sanchez, C., Lagomasino, D., Davis, S.E., 2015. Component-specific dynamics of riverine mangrove CO 2 efflux in the Florida coastal Everglades. Agric. For. Meteorol. 213, 273-282.

Van Dover, C.L., Grassle, J.F., Fry, B., Garritt, R.H., Starczak, V.R., 1992. Stable isotope evidence for entry of sewage-derived organic material into a deep-seafood-web. Nature 360, 153-156.

Walton, M.E.M., Al-Maslamani, I., Skov, M.W., Al-Shaikh, I., Al-Ansari, I.S., Kennedy, H.A., Vay, L.L., 2014. Outwelling from arid mangrove systems is sustained by inwelling of seagrass productivity. Mar. Ecol. Prog. Ser. 507, 125-137. 